\title{
Molecular Characterization and Pathogenicity of Infectious Bronchitis Coronaviruses: Complicated Evolution and Epidemiology in China Caused by Cocirculation of Multiple Types of Infectious Bronchitis Coronaviruses
}

\author{
Shengwang Liu Xiaonan Zhang Yu Wang Chengren Li Zongxi Han \\ Yuhao Shao Huixin Li Xiangang Kong \\ Division of Avian Infectious Diseases, National Key Laboratory of Veterinary Biotechnology, Harbin Veterinary \\ Research Institute, Chinese Academy of Agricultural Sciences, Harbin, PR China
}

\section{Key Words}

Avian infectious bronchitis coronavirus - Mutation •

Insertion and deletion - Recombination · Pathogenicity

\begin{abstract}
Objective: To monitor and study the molecular epidemiology, evolution and pathogenicity of infectious bronchitis viruses (IBVs) in China in recent years and further our knowledge of the evolution of IBVs. Methods: Thirty-seven IBV isolates were isolated from commercial chickens in China. The isolates were characterized by RT-PCR, sequencing, typing and analyzing the entire S1 gene. In addition, 4 selected IBV isolates were used to experimentally infect the specific pathogen-free chickens to study their pathogenicity. $\boldsymbol{R} \boldsymbol{e}$ sults: Three types of IBV have been cocirculating in chicken flocks in China in recent years. Unique insertions and deletions in S1 protein regions were identified among different types of IBV. Moreover, a new IBV strain was isolated and identified in a layer hen. S1 gene analysis showed that a recombination event had occurred in the virus's evolutionary process. In addition, experimental infection has shown that IBV isolates have been nephropathogenic in China in recent years. Conclusion: Mutations, insertions, deletions and re-
\end{abstract}

combination of the S1 protein gene contribute to the genetic diversity of IBV in China. Cocirculation of multiple types of IBV in field conditions in China renders its epidemiology and evolution very complicated, indicating the necessity for development of new vaccines or vaccine strategies.

Copyright $\odot 2009$ S. Karger AG, Basel

\section{Introduction}

Avian infectious bronchitis virus (IBV) is one of the major poultry pathogens, and is probably endemic in all regions where poultry are reared intesively. It is a Group 3 member in the genus Coronavirus, based on genetic and antigenic characteristics [1]. Its genome consists of a single-stranded positive RNA molecule (approx. $27.6 \mathrm{~kb}$ ) that encodes 4 structural proteins: the spike (S), membrane $(\mathrm{M})$, small membrane (E) and nucleoprotein $(\mathrm{N})$. The multimeric coiled-coil S protein is post-translationally cleaved into the amino-terminal S1 (92 kDa) and the carboxyl-terminal S2 $(84 \mathrm{kDa})$ subunit. The S1 protein, which is anchored to the membrane by association with $\mathrm{S} 2$, is involved in virus entry and also contains epitopes for virus-neutralizing and hemagglutination-inhibiting

\section{KARGER}

Fax +4161306 1234 E-Mail karger@karger.ch www.karger.com (c) 2009 S. Karger AG, Basel

0300-5526/09/0524-0223\$26.00/0

Accessible online at:

www.karger.com/int
Shengwang Liu, Division of Avian Infectious Diseases

National Key Laboratory of Veterinary Biotechnology

Harbin Veterinary Research Institute

Chinese Academy of Agricultural Sciences, Harbin 150001 (PR China)

Tel. +86 4518593 5065, Fax +86 4518273 4181, E-Mail swliu@hvri.ac.cn 
antibodies [2-6]. The S1 sequences from different strains vary significantly, usually by between 2 and $25 \%$ at the amino acid level [2].

It is well known that the primary problem in the control of infectious bronchitis (IB) is the ability of the virus to generate antigenic diversity. Genetic diversity among IBV is generated by point mutations, insertions and deletions introduced into the viral genome by viral RNA-dependent RNA polymerases, which lack proofreading capabilities, and by genetic recombination, which occurs via a genomic template-switching mechanism [7]. This has led to the continuous emergence of new IBV serotypes or variants and has complicated the design of appropriate control programs due to the low degree of cross-protection observed among IBV serotypes. Further, this indicates the necessity for accurate techniques to isolate, identify and constantly monitor this viral agent. S1 gene sequencing and subsequent genetic analysis provide a fast and accurate method for classifying and predicting IBV serotypes, and have been used for molecular epidemiological studies and genotypic characterization of IBV [8-19].

Since the early 1980s, IBV has been diagnosed in China by virus isolation. Since then, epidemiological surveys among different regions in China have shown that IB is one of the main infectious diseases affecting farms [2027]. At least 3 important factors have made IB occurrence very complicated in China. First, farms in China have an extremely large number of chickens that are, in most cases, maintained at high density, which allows the virus to spread easily. Second, several types of the available IB vaccines belong to serotypes that are different from those of the endemic IBV strains and so bestow only a low degree of protection against the field strains, such as Masstype (Ma5, H52 and H120), Connecticut-type, 4/91, 28/86 and W93. These have been used intensively in China, and in most cases have been co-used within flocks. Third, several types of IBVs have been found to co-circulate in chicken flocks in China $[21,23,24,27]$. Hence, IBV may consistently exist and mutation occurrence is possible in the course of IBV evolutionary process. Meanwhile, a given cell co-infected with more than 1 IBV serotype has led to the possibility of recombination. Consequently, to monitor and study the molecular epidemiology of IBVs in China is of significance in order to provide a guide to the optimal use of existing live vaccines and to alert the industry to the need for development of new vaccines or vaccine strategies. The purpose of this study is not only to study IBV evolution, but also to extend our knowledge of the molecular epidemiology of the IBV field isolates recently circulating in China.

\section{Materials and Methods}

\section{Viruses}

Thirty-seven tissue samples of kidney, proventriculus, trachea and cecal tonsil from 37 IB suspected broiler or layer flocks covering most chicken raising regions of China in 2007 were collected and used for IBV isolation (table 1). For virus isolation, samples of tissue were pooled and $10 \% \mathrm{w} / \mathrm{v}$ tissue suspensions were made in $0.1 \%$ phosphate-buffered saline (PBS) containing $100 \mathrm{U}$ penicillin and $100 \mu \mathrm{g}$ streptomycin/ml. After $12 \mathrm{~h}$ at $4^{\circ}, 200 \mu \mathrm{l}$ supernatant from the suspensions was inoculated into the allantoic cavity of 9- to 11-day-old embryos of specific pathogen-free (SPF) chickens (Harbin Veterinary Research Institute, China). Between 3 and 5 eggs were used for each sample. The inoculated eggs were incubated at $37^{\circ}$ and handled daily. Between 1 and 5 blind passages were performed until characteristic embryo changes, such as dwarfing, stunting or curling, were observed between 2 and 7 days after inoculation, according to a previous report [23]. All allantoic fluids of inoculated eggs were harvested and tested for the presence of IBV using electron microscopy.

\section{Electron Microscopy}

Samples of allantoic fluid after egg passages were submitted for electron microscopy. Briefly, after low-speed centrifugation at $1,500 \mathrm{~g}$ for $30 \mathrm{~min}$ (Allegra ${ }^{\mathrm{TM}} 21 \mathrm{R}$ centrifuge; Beckman, USA), the supernatants of the $1.5 \mathrm{ml}$ allantoic fluid were centrifuged at $12,000 \mathrm{~g}$ for $30 \mathrm{~min}$. The resulting pellet was resuspended in a minimal volume of deionized water and examined by negative contrast electron microscope (JEM-1200, EX).

Viral RNA Extraction, RT-PCR Amplification and Sequencing

Genomic RNA was extracted from infected allantoic fluid with Trizol reagent (Invitrogen, USA) according to the manufacturer's instructions. The first-strand cDNA was synthesized according the procedures of a previous report [23] using genomic antisense oligonucleotides S1Oligo3' (5'-CATAACTAACATAAGGGCAA$\left.3^{\prime}\right)$ and IBV-212 (5'-ATACAAAATCTGCCATAA-3'). The PCR profiles involved an initial denaturation step for $5 \mathrm{~min}$ at $95^{\circ}$ followed by 30 cycles of denaturation at $94^{\circ}$ for $1 \mathrm{~min}$, annealing at $50^{\circ}$ for $1 \mathrm{~min}$, and polymerization at $72^{\circ}$ for $2 \mathrm{~min}$. The final polymerization step was performed at $72^{\circ}$ for $10 \mathrm{~min}$. Two genome sense oligonucleotides, IBV-257 (5'-TATTGATTAGAGATGTGG$\left.3^{\prime}\right)$ and S1Oligo5' (5'-TGAAAACTGAACAAAAGAC-3'), were used with S1Oligo3' or IBV-212 as antisense primers in PCR amplification. The PCR products were analyzed on a $1.0 \%$ agarose gel and were directly sequenced. Meanwhile, the PCR products were also sequenced after cloning into the pMD18-T vector (TaKaRa, Japan). Each region was sequenced at least 3 times and the consensus sequence was determined.

\section{Phylogenetic Analysis of S1 Protein Genes}

The nucleotide and amino acid sequences of the S1 protein gene of the IBV isolates were assembled, aligned and compared with other reference IBV strains using the MegAlign program in DNAStar. Phylogenetic analysis of the deduced amino acid sequences of the S1 protein gene was performed with the Clustal V method in DNAStar software [15]. A total of 27 IBV reference strains were selected for phylogenetic analysis in this study. The selected IBV reference strains and their accession numbers are listed in table 2. Of these, most represented Chinese IBV field iso- 
Table 1. Epidemiology information for Chinese field IBV isolates included in this study

\begin{tabular}{|c|c|c|c|c|c|}
\hline IBV Isolates & Province (city) ${ }^{\mathrm{a}}$ & $\begin{array}{l}\text { Vaccines used } \\
\text { for vaccination }\end{array}$ & $\begin{array}{l}\text { Organs used for } \\
\text { virus isolation }^{\mathrm{b}}\end{array}$ & $\begin{array}{l}\text { Production } \\
\text { type }\end{array}$ & $\begin{array}{l}\text { Accession } \\
\text { number }\end{array}$ \\
\hline $\mathrm{ck} / \mathrm{CH} / \mathrm{LDL} / 07 \mathrm{I}$ & Dalan & $4 / 91$ & kidney & layer hen & FJ345364 \\
\hline $\mathrm{ck} / \mathrm{CH} / \mathrm{LDL} / 07 \mathrm{II}$ & Dalan & Ma5 & proventriculus & layer hen & EU563940 \\
\hline $\mathrm{ck} / \mathrm{CH} / \mathrm{LDL} / 07 \mathrm{III}$ & Dalan & $\mathrm{Ma} 5+4 / 91$ & kidney & layer hen & FJ345365 \\
\hline ck/CH/LSD/07II & Shandong (Linyi) & 28/86+Ma5 & trachea & broiler & FJ345384 \\
\hline $\mathrm{ck} / \mathrm{CH} / \mathrm{LSD} / 07 \mathrm{I}$ & Shandong (Weifang) & 28/86+Ma5 & proventriculus & Layer hen & EU563941 \\
\hline $\mathrm{ck} / \mathrm{CH} / \mathrm{LSD} / 07 \mathrm{III}$ & Shandong (Tancheng) & 28/86+Ma5 & kidney & broiler & FJ345385 \\
\hline $\mathrm{ck} / \mathrm{CH} / \mathrm{LSD} / 07 \mathrm{IV}$ & Shandong (Linyi) & 28/86+Ma5 & kidney & layer hen & FJ345386 \\
\hline $\mathrm{ck} / \mathrm{CH} / \mathrm{LSD} / 07 \mathrm{~V}$ & Shandong (Shouguang) & $\mathrm{H} 120$ & kidney & broiler & FJ345388 \\
\hline $\mathrm{ck} / \mathrm{CH} / \mathrm{LSD} / 07 \mathrm{VI}$ & Shandong (Taian) & 28/86+Ma5 & kidney & broiler & FJ345389 \\
\hline ck/CH/LSD/07VII & Shandong (Linyi) & 28/86+Ma5 & kidney & broiler & FJ345390 \\
\hline $\mathrm{ck} / \mathrm{CH} / \mathrm{LSD} / 07 \mathrm{VIII}$ & Shandong (Taian) & 28/86+Ma5 & kidney & broiler & FJ345391 \\
\hline ck/CH/LSD/07IX & Shandong (Gaomi) & $\mathrm{H} 120+28 / 86$ & kidney & broiler & FJ345387 \\
\hline $\mathrm{ck} / \mathrm{CH} / \mathrm{LSD} / 07 \mathrm{X}$ & Shandong (Anqiu) & $\mathrm{H} 120+28 / 86$ & proventriculus & layer hen & FJ345392 \\
\hline $\mathrm{ck} / \mathrm{CH} / \mathrm{LSD} / 07 \mathrm{XI}$ & Shandong (Penglai) & $\mathrm{H} 120$ & trachea & broiler & FJ345393 \\
\hline $\mathrm{ck} / \mathrm{CH} / \mathrm{LSD} / 07 \mathrm{XII}$ & Shandong (Qingdao) & $4 / 91$ & kidney & broiler & FJ345394 \\
\hline $\mathrm{ck} / \mathrm{CH} / \mathrm{LSD} / 07-1$ & Shandong (Shouguang) & $\mathrm{H} 120$ & kidney & broiler & FJ345381 \\
\hline $\mathrm{ck} / \mathrm{CH} / \mathrm{LSD} / 07-2$ & Shandong (Shouguang) & $4 / 91$ & kidney & broiler & FJ345382 \\
\hline $\mathrm{ck} / \mathrm{CH} / \mathrm{LSD} / 07-3$ & Shandong (Shouguang) & $4 / 91$ & kidney & broiler & FJ345383 \\
\hline $\mathrm{ck} / \mathrm{CH} / \mathrm{LSD} / 07-4$ & Shandong (Weifang) & $\mathrm{H} 120$ & kidney & layer hen & FJ345395 \\
\hline ck/CH/LJS/07I & Jiangsu (Haian) & $\mathrm{H} 120$ & kidney & layer hen & FJ345376 \\
\hline ck/CH/LJS/07II & Jiangsu (Qingjiang) & $\mathrm{H} 120$ & kidney & broiler & FJ345377 \\
\hline $\mathrm{ck} / \mathrm{CH} / \mathrm{LJS} / 07 \mathrm{IV}$ & Jiangsu (Rugao) & Non-vaccinated & kidney & broiler & FJ345378 \\
\hline $\mathrm{ck} / \mathrm{CH} / \mathrm{LJS} / 07 \mathrm{~V}$ & Jiangsu (Wuxi) & Ma5 & kidney & layer hen & FJ345379 \\
\hline ck/CH/LJL/07I & Jilin (Dehui) & $\mathrm{H} 120$ & kidney & broiler & FJ345373 \\
\hline ck/CH/LJL/07II & Jilin (Dehui) & $\mathrm{H} 120+\mathrm{Ma} 5$ & kidney & layer hen & FJ345374 \\
\hline ck/CH/LJL/07III & Jilin (Changchun) & $\mathrm{Ma} 5+\mathrm{H} 120$ & kidney & layer hen & FJ345375 \\
\hline $\mathrm{ck} / \mathrm{CH} / \mathrm{LJL} / 07 \mathrm{~V}$ & Jilin (Changchun) & $\mathrm{H} 120$ & proventriculus & broiler & EU563944 \\
\hline $\mathrm{ck} / \mathrm{CH} / \mathrm{LHLJ} / 07 \mathrm{I}$ & Heilongjiang (Nehe) & $\mathrm{H} 120$ & kidney & layer hen & EU563942 \\
\hline ck/CH/LHLJ/07III & Heilongjiang (Wangkui) & $28 / 86$ & cecal tonsil & layer hen & FJ345366 \\
\hline ck/CH/LHLJ/07IV & Heilongjiang (Zhaodong) & $\mathrm{H} 120$ & cecal tonsil & layer hen & FJ345367 \\
\hline $\mathrm{ck} / \mathrm{CH} / \mathrm{LHLJ} / 07 \mathrm{~V}$ & Heilongjiang (Harbin) & $28 / 86$ & proventriculus & layer hen & EU563943 \\
\hline ck/CH/LHLJ/07VI & Heilongjiang (Qiqihar) & 28/86+Ma5 & kidney & layer hen & FJ345368 \\
\hline $\mathrm{ck} / \mathrm{CH} / \mathrm{LHLJ} / 07 \mathrm{VII}$ & Heilongjiang (Qiqihar) & $\mathrm{H} 120+4 / 91$ & kidney & layer hen & FJ345369 \\
\hline $\mathrm{ck} / \mathrm{CH} / \mathrm{LHN} / 07 \mathrm{I}$ & Helan (Puyang) & H120 & kidney & layer hen & FJ345370 \\
\hline ck/CH/LHN/07II & Helan (Puyang) & $\mathrm{H} 120+28 / 86$ & kidney & layer hen & FJ345371 \\
\hline $\mathrm{ck} / \mathrm{CH} / \mathrm{LHN} / 07 \mathrm{III}$ & Helan (Puyang) & $\mathrm{H} 120$ & kidney & layer hen & FJ345372 \\
\hline ck/CH/LLN/07I & Liaonin (Liaoyang) & $\mathrm{H} 120$ & kidney & layer hen & FJ345380 \\
\hline
\end{tabular}

\footnotetext{
${ }^{\text {a }}$ Province (city) where the viruses were isolated.

${ }^{\mathrm{b}}$ Kidney = Swollen kidney; proventriculus = swollen proventriculus; cecal tonsil = hemorrhagic cecal tonsil; trachea = hemorrhagic trachea.
}

lates available in the GenBank database [28]. In addition, the S1 protein genes of Mass-type strains were also selected and compared in this study $[29,30]$ because these types of vaccines were widely used for many years on poultry farms in China.

\section{S1 Nucleotide and Deduced Amino Acid Sequence}

Comparison and Analysis

Two classical LX4-type strains (LX4 [23] and QXIBV), 12 Mass-type and $14 \mathrm{CK} / \mathrm{CH} / \mathrm{LSC} / 99 \mathrm{I}-$ type reference strains were selected for insertion and deletion comparison in S1 protein re- gions with our isolates. The $\mathrm{S} 1$ amino acid sequences of reference IBV strains and our IBV isolates were assembled, aligned and compared.

The nucleotide and amino acid sequences of the S1 gene of the isolate ck/CH/LHLJ/07VII were assembled, aligned, and compared with the other 12 Mass-type reference IBV strains. Of the 12 reference IBV strains, 3 vaccine strains were used widely in chicken flocks in China, 3 Chinese field isolates were isolated in different years by different study groups from different hosts [21, 27], and 2 American classical strains (M41 and Beaudette) [28, 29] 
Table 2. IBV strains used for sequence comparison of the $\mathrm{S} 1$ gene in this study

\begin{tabular}{|c|c|c|c|c|c|}
\hline IBV strain & Type $^{\mathrm{a}}$ & Geographic origin & Original description & Host & $\begin{array}{l}\text { Accession } \\
\text { number }\end{array}$ \\
\hline LX4 & LX4 & Xinjiang province, China & Liu and Kong, 2004 [23] & chicken & AY189157 \\
\hline QXIBV & LX4 & Shandong province, China & Pan et al., 1999 [unpubl.] & chicken & AF193423 \\
\hline $\mathrm{CK} / \mathrm{CH} / \mathrm{LSC} / 99 \mathrm{I}$ & $\mathrm{CK} / \mathrm{CH} / \mathrm{LSC} / 99 \mathrm{I}$ & Sichuan province, China & Liu et al., 2006 [15] & chicken & DQ167147 \\
\hline $\mathrm{CK} / \mathrm{CH} / \mathrm{LGD} / 04 \mathrm{II}$ & $\mathrm{CK} / \mathrm{CH} / \mathrm{LSC} / 99 \mathrm{I}$ & Guangdong province, China & Liu et al., 2006 [15] & chicken & DQ167134 \\
\hline $\mathrm{CK} / \mathrm{CH} / \mathrm{LDL} / 04 \mathrm{II}$ & CK/CH/LSC/99I & Dalan, China & Liu et al., 2006 [15] & chicken & DQ167131 \\
\hline $\mathrm{CK} / \mathrm{CH} / \mathrm{LDL} / 05 \mathrm{I}$ & $\mathrm{CK} / \mathrm{CH} / \mathrm{LSC} / 99 \mathrm{I}$ & Dalan, China & Liu et al., 2008 [27] & chicken & EF213563 \\
\hline $\mathrm{CK} / \mathrm{CH} / \mathrm{LNM} / 05 \mathrm{I}$ & $\mathrm{CK} / \mathrm{CH} / \mathrm{LSC} / 99 \mathrm{I}$ & Neimeng province, China & Liu et al., 2008 [27] & chicken & EF213567 \\
\hline $\mathrm{CK} / \mathrm{CH} / \mathrm{LGX} / 06 \mathrm{I}$ & $\mathrm{CK} / \mathrm{CH} / \mathrm{LSC} / 99 \mathrm{I}$ & Guangxi province, China & Liu et al., 2008 [27] & chicken & EF213580 \\
\hline $\mathrm{SH} 2$ & $\mathrm{CK} / \mathrm{CH} / \mathrm{LSC} / 99 \mathrm{I}$ & Shanghai, China & Qian et al., 2005 [unpubl.] & chicken & DQ075324 \\
\hline $\mathrm{J}$ & $\mathrm{CK} / \mathrm{CH} / \mathrm{LSC} / 99 \mathrm{I}$ & Zhejiang province, China & Zhou et al., 2005 [unpubl.] & chicken & AF352312 \\
\hline SC021202 & $\mathrm{CK} / \mathrm{CH} / \mathrm{LSC} / 99 \mathrm{I}$ & Sichuan province, China & Zhou et al., 2004 [unpubl.] & chicken & AY237817 \\
\hline YN05-1 & CK/CH/LSC/99I & Yunnan province, China & Xu et al., 2007 [25] & chicken & DQ459474 \\
\hline CQ04-1 & $\mathrm{CK} / \mathrm{CH} / \mathrm{LSC} / 99 \mathrm{I}$ & Chongqing, China & Xu et al., 2007 [25] & chicken & DQ459476 \\
\hline SC03-1 & CK/CH/LSC/99I & Sichuan province, China & Xu et al., 2007 [25] & chicken & DQ459472 \\
\hline BJ03-1 & $\mathrm{CK} / \mathrm{CH} / \mathrm{LSC} / 99 \mathrm{I}$ & Beijing, China & Xu et al., 2007 [25] & chicken & DQ459475 \\
\hline PSH050513 & CK/CH/LSC/99I & Shanghai, China & Qian et al., 2006 [28] & pigeon & DQ160004 \\
\hline $\mathrm{H} 120$ & Mass & Vaccine strain & Bijlenga et al., 2004 [29] & chicken & M21970 \\
\hline IBN & Mass & Vaccine strain & Liu et al., 2006 [30] & chicken & AY856348 \\
\hline W93 & Mass & Vaccine strain & Liu et al., 2006 [30] & chicken & AY842862 \\
\hline $\mathrm{BJ} 1$ & Mass & Beijing, China & Li and Yang, 2003 [21] & chicken & AF347018 \\
\hline $\mathrm{pf} / \mathrm{CH} / \mathrm{LKQ} 3 / 03$ & Mass & Guangdong, China & Liu et al., 2005 [26] & peafowl & AY702085 \\
\hline $\mathrm{SD} / 97 / 01$ & Mass & Shandong, China & Pan et al., 1997 [unpubl.] & chicken & AF208240 \\
\hline M41 & Mass & America & Callison et al., 2006 [32] & chicken & AY851295 \\
\hline Beaudette & Mass & America & Boursnell et al., 1987 [31] & chicken & NC_001451 \\
\hline Spain/98/308 & Mass & Spain & Dolz et al., 2008 [19] & chicken & DQ064807 \\
\hline KB8523 & Mass & South Korea & Sutou et al., 1988 [33] & chicken & M21515 \\
\hline JP/Ishida/51 & Mass & Japan & Mase et al., 2004 [16] & chicken & AB120628 \\
\hline $2994 / 02$ & Mass & Taiwan & Huang et al., 2004 [34] & chicken & AY606324 \\
\hline $\mathrm{tl} / \mathrm{CH} / \mathrm{LDT} 3 / 03$ & $\mathrm{tl} / \mathrm{CH} / \mathrm{LDT} 3 / 03$ & Guangdong, China & Liu et al., 2005 [26] & chicken & AY702975 \\
\hline $\mathrm{CK} / \mathrm{CH} / \mathrm{LSD} / 05 \mathrm{I}$ & variant & Shandong, China & Liu et al., 2008 [27] & chicken & EF213568 \\
\hline
\end{tabular}

a Based on S1 gene sequence.

and an additional 4 strains from European countries [19], Japan [30], South Korea [31] and Taiwan [32] were also selected (table 2). The entire coding region of the $\mathrm{S} 1$ gene of these strains was chosen for analysis except for the BJ1 and JP/Ishida/51 strains, for which complete S1 gene sequences were not available in the GenBank database.

In addition, 2 reference strains, $\mathrm{tl} / \mathrm{CH} / \mathrm{LDT} 3 / 03$ and $\mathrm{CK} / \mathrm{CH} /$ LSD/05I, were used for S1 protein gene comparison with that of isolate ck/CH/LSD/07-4. All nucleotide and amino acid alignments were performed using MegAlign.

The backgrounds of the reference strains used in this study and their accession numbers are listed in table 2.

\section{GenBank Accession Numbers}

All nucleotide sequences of S1 protein gene of our IBV isolates reported herein have been submitted to the GenBank database and their accession numbers are listed in table 1.
Virulence Study

In order to study the pathogenicity of the different IBV isolates circulating in China in recent years, 4 IBV isolates (table 3), which were isolated from the kidney, proventriculus or cecal tonsil of chickens and which belonged to 2 different types (fig. 1), were used for inoculation in SPF chickens. Five groups of 10 White Leghorn FPF chickens (Harbin Veterinary Research Institute, China) were kept in isolators with negative pressure. At the age of 15 days, groups 1-4 were inoculated intranasally with each of the 4 isolates $\left[\log 10^{5.2}\right.$ to $\log 10^{5.3}$ median embryo infectious doses $\left(\mathrm{EID}_{50}\right)$ per chick; table 3]. The remaining group (group 5) was mock-inoculated with sterile allantoic fluid and served as a control. The chicks were examined daily for signs of infection for 30 days after inoculation. Meanwhile, blood samples from all birds in each group were collected at 5, 10, 15 and 20 days after inoculation. The serum was stored at $-70^{\circ}$ until ELISA testing.

The study was approved by the animal welfare committee of Heilongjiang Province, China. 
Table 3. Morbidity and mortality after challenge with 4 IBV isolates recently isolated in China

\begin{tabular}{|c|c|c|c|c|c|c|c|c|}
\hline \multirow[t]{2}{*}{ Virus isolate } & \multirow[t]{2}{*}{ Type } & \multirow{2}{*}{$\begin{array}{l}\text { Dose, median } \\
\text { embryo infectious } \\
\text { doses }\left(\log _{10}\right)^{\mathrm{a}}\end{array}$} & \multirow{2}{*}{$\begin{array}{l}\text { Diseased } \\
\text { chickss }^{\mathrm{b}}\end{array}$} & \multirow{2}{*}{$\begin{array}{l}\text { Dead } \\
\text { chicks }^{\mathrm{c}}\end{array}$} & \multicolumn{4}{|c|}{ Antibody response ${ }^{\mathrm{d}}$} \\
\hline & & & & & 5 days $^{e}$ & 10 days $^{\mathrm{e}}$ & 15 days $^{\mathrm{e}}$ & 20 days $^{\mathrm{e}}$ \\
\hline $\mathrm{ck} / \mathrm{CH} / \mathrm{LSD} / 07 \mathrm{I}$ & LX4 & 5.3 & $10 / 10(100)$ & $2 / 10(20)$ & $1 / 10(10)$ & $6 / 8(75)$ & $8 / 8(100)$ & $8 / 8(100)$ \\
\hline $\mathrm{ck} / \mathrm{CH} / \mathrm{LJL} / 07 \mathrm{~V}$ & LX4 & 5.2 & $10 / 10(100)$ & $4 / 10(40)$ & $2 / 9(22.2)$ & $3 / 6(50)$ & $6 / 6(100)$ & $6 / 6(100)$ \\
\hline $\mathrm{ck} / \mathrm{CH} / \mathrm{LHLJ} / 07 \mathrm{IV}$ & LX4 & 5.3 & $10 / 10(100)$ & $3 / 10(30)$ & $1 / 10(10)$ & $5 / 8(62.5)$ & $7 / 7(100)$ & $7 / 7(100)$ \\
\hline $\mathrm{ck} / \mathrm{CH} / \mathrm{LDL} / 07 \mathrm{I}$ & CK/CH/LSC/99I & 5.3 & $10 / 10(100)$ & $3 / 10(30)$ & $0 / 9(0)$ & $6 / 8(75)$ & $7 / 7(100)$ & $7 / 7(100)$ \\
\hline Control & - & $\begin{array}{l}\text { Sterile } \\
\text { allantoic fluid }\end{array}$ & $0 / 10(0)$ & $0 / 10(0)$ & $0(0)$ & $0(0)$ & $0(0)$ & $0(0)$ \\
\hline
\end{tabular}

\footnotetext{
Numbers in parentheses are percentages. There were 10 chicks in each group.

${ }^{\mathrm{a}}$ Dose per chick $=100 \mathrm{ml} .{ }^{\mathrm{b}}$ Number clinical signs/number challenged. ${ }^{\mathrm{c}}$ Number died during the experiment/number challenged. ${ }^{\mathrm{d}}$ Number seroconverted/number challenged. ${ }^{\mathrm{e}}$ Days after challenge.
}

Total Antibody ELISA

Serum samples were assayed in single dilutions using a commercial total antibody ELISA (IDEXX Corporation, Westbrook, Me., USA) according to the manufacturer's instructions. Serumto-positive ratios were calculated as described previously [30, 35]. From these ratios, individual serum titers, expressed as $\log _{2}$ values, were calculated according to the manufacturer's instructions.

\section{Results}

\section{S1 Gene Phylogenetic Analysis: LX4 Was the}

Predominant Type of IBV Co-Circulating in Chinese

Chicken Flocks

All the diseased chickens from which tissue samples were collected showed clinical IB symptoms and nephritis, and had no more than $50 \%$ mortality. Some of the chickens showed hemorrhagic lesions of cecal tonsils and proventriculitis. Thirty-seven kidney, proventriculus, trachea and cecal tonsil tissue samples were positive for IBV isolation and detection and were used in this study. Typical signs, including embryo dwarfing and death, were observed in different passages when each tissue sample or isolate was inoculated into embryos. Diagnoses based on electron microscopy examination showed all isolates had typical coronavirus morphology and were free of other agents such as Newcastle disease virus (results not shown).

Phylogenetic analysis based on $\mathrm{S} 1$ amino acid sequences of our 36 isolates and 27 reference IBV strains showed that our 36 isolates were separated into 3 groups or genotypes (fig. 1). Most of the IBV isolates in this study belonged to the LX4-type (33 out of 36). These LX4-type isolates had $93.1-99.9 \%$ and $94.5-99.9 \%$ nucleotide and amino acid similarities, respectively, between each other. These IBV isolates shared $93.9-95.5 \%$ and $95.1-96.9 \%$ nucleotide and amino acid similarities, respectively, to S1 from the previously isolated LX4 strains [23]. Isolate ck/ $\mathrm{CH} / \mathrm{LHLJ} / 07 \mathrm{VII}$ was grouped into Mass-type. Two isolates, ck/CH/LDL/07III and ck/CH/LDL/07III, were CK/ $\mathrm{CH} / \mathrm{LSC}$ /99I-type viruses and showed a closer relationship with IBV strains isolated in the same region (Dalan, China) from 2004 to 2005. The phylogenetic analysis of the nucleotide sequences for the analyzed S1 gene was consistent with that based on the amino acid sequences (not shown).

\section{Analysis of S1 Gene Sequences from ck/CH/LSD/07-4}

Indicated Direct Evidence of Recombination Event

The Blast searches that were conducted using the entire $S 1$ gene (from the first 1,620 nucleotides, starting at the AUG translation start codon) revealed that isolate ck/ $\mathrm{CH} / \mathrm{LSD} / 07-4$ was most closely related to the IBV strain $\mathrm{tl} / \mathrm{CH} / \mathrm{LDT} 3 / 03$. As shown in figure 2 and table $3, \mathrm{ck} / \mathrm{CH} /$ LSD/07-4 shared 92.8 and $92.1 \%$ nucleotide similarity with the entire S1 gene of the published Chinese IBV isolates, $\mathrm{tl} / \mathrm{CH} / \mathrm{LDT} 3 / 03$ and $\mathrm{CK} / \mathrm{CH} / \mathrm{LSD} / 05 \mathrm{I}$, respectively. However, ck/CH/LSD/07-4 had 100\% identity with the S1 gene of CK/CH/LSD/05I from nucleotide positions 1 to 582 but only $80.9 \%$ identity between nucleotide positions 622 and 1,620, whereas ck/CH/LSD/07-4 shared no more than $87.3 \%$ nucleotide identity with the $\mathrm{S} 1$ gene of CK/CH/LSD/05I from 1 to 582 but $99.3 \%$ from 622 to 1,620 (table 4), indicating that a recombination event had occurred in the IBV evolutionary process. 


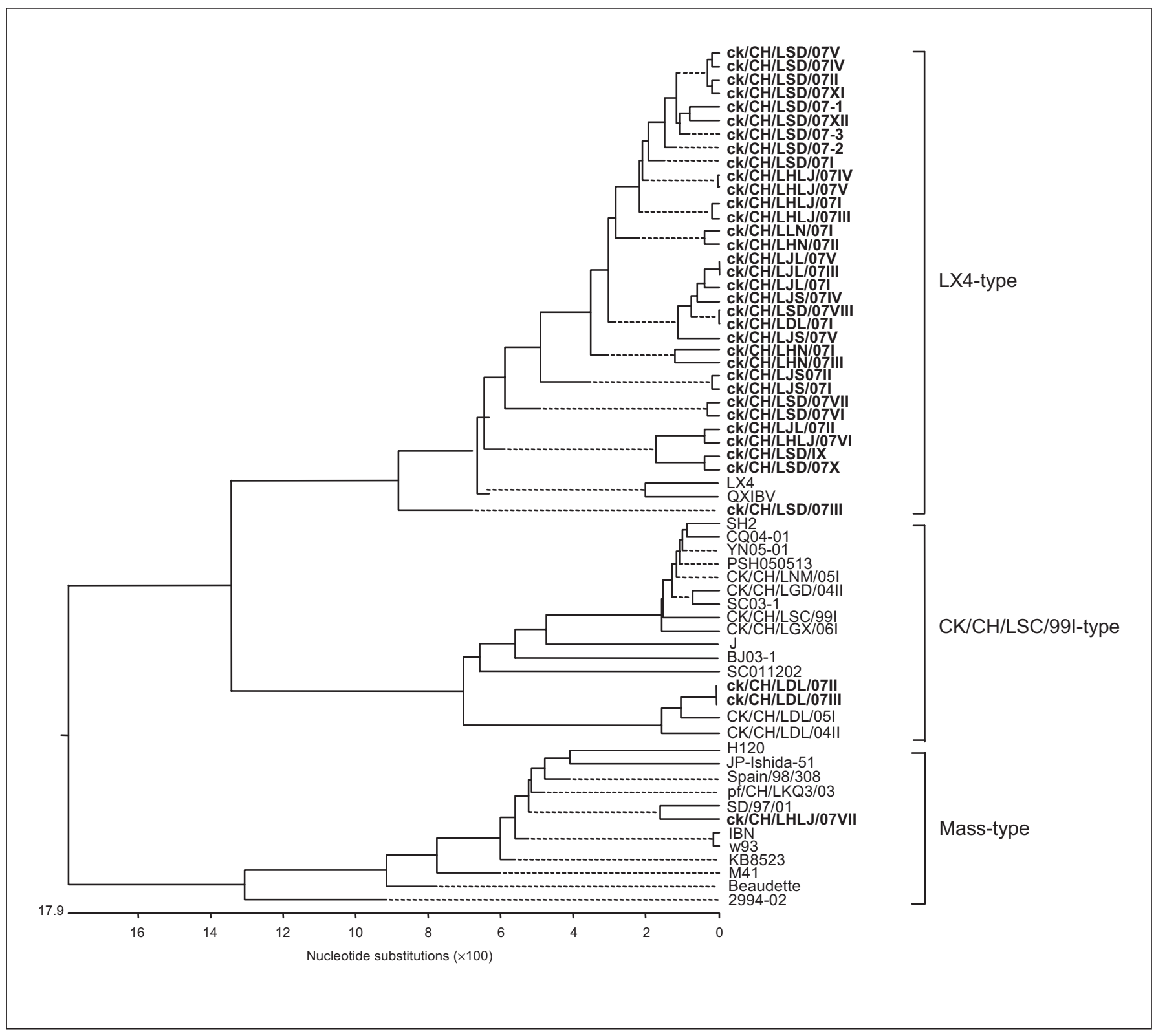

Fig. 1. Phylogenetic tree constructed using neighbor-joining based on the S1 subunit of spike protein. The tree was rooted with the first 1,662 nucleotides, starting at the AUG translation initiation codon, of the S protein genes. Our IBV isolates are in bold type.

Sequence Analysis: There Are Sequence Markers among Different Types of IBV due to Unique Deletions and Insertions in $\mathrm{S} 1$ Region

A total of 35 Chinese LX4-type field isolates (33 from the present study and 2 previously described), 15 field isolates of $\mathrm{CK} / \mathrm{CH} / \mathrm{LSC} / 99 \mathrm{I}-$ type (2 from the present study and 14 from the GenBank database) and 13 IBV strains of Mass-type (3 vaccine strains and 10 isolates from different countries of the world) were included in the present study, and the S1 amino acid sequences were compared. As shown in figure 3, we observed 3 unique amino acid sequence deletions and insertions in S1 protein regions among the 3 different types of IBV strains. Compared with Mass-type IBVs, the first region was in positions 72-78. Seven amino acids were deleted in LX4type IBVs; however, CK/CH/LSC/99I-type IBVs had 4 
Color version available online

TACTGGTGTTAAGTCAGCAGGTGTGTATTTTAAGGCAGGTGGACCTGTAAATTATAATATTATGAAAGAATTTAAGGTTCTGGCTTATTTTGTCAATGGTACTGTGCAAGATGTAATTC 1 CAAGGATGTCACATCAGCAGGTGTGTATTTTAAAGCAGGTGGACCTGTAAATTATAATATTATGAAAGAATTTAAGGTTCTGGCTTATTTTGTCAATGGTACTGTGCAAGATGTAATTC 2 CAAGGATGTCACATCAGCAGGTGTGTATTTTAAAGCAGGTGGACCTGTAAATTATAATATTATGAAAGAATTTCAGGTACTTGCTTATTTTGTTAATGGGACTGTACAAGACGTTATCT 3

Fig. 2. Sequencing and sequence alignment of the potential recombination junction site and flanked sequences. The potential recombination junction site was underlined. Nucleotides that are identical between 2 of the 3 sequences but different from the rest are indicated in red. Figures and represented numbers are: $1 \mathrm{tl} / \mathrm{CH} / \mathrm{LDT} 3 / 03$, $2 \mathrm{ck} / \mathrm{CH} / \mathrm{LSD} / 07-4$ and $3 \mathrm{CK} / \mathrm{CH} / \mathrm{LSD} / 05 \mathrm{I}$.

amino acid insertions. The second region was between positions 82 and 85 . Three amino acids were inserted in LX4-type IBVs; however, CK/CH/LSC/99I-type IBVs had 4 amino acid insertions. The last region was between positions 127 and 130. Two amino acids were inserted in LX4-type IBVs; however, CK/CH/LSC/99I-type IBVs had 1 amino acid deletion.

\section{Genetic Comparison: ck/CH/LHLJ/07VII Was a}

Mass-Type Field Strain Isolated in Vaccinated

Chicken Flock

A Mass-type IBV isolate, ck/CH/LHLJ/07VII, was isolated from kidneys of an H120 and 4/91-immunized layer hen in Heilongjiang province. Our RT-PCR method could not distinguish between the vaccine and field virus of the same genotype. We compared the sequence of this virus with those of the standard vaccine strains and reference field strains. Table 5 presents the percentage of detections of ck/CH/LHLJ/07VII with reference strains. Isolate ck/CH/LHLJ/07VII shared the maximum S1 nucleotide and amino acid identities (99 and 97.1\%, respectively) with a Chinese field strain, SD/97/01, which was isolated in 1997 in Shandong province, China. Meanwhile, 18 unique nucleotide mutations and 15 amino acid substitutions were found in the $\mathrm{S} 1$ protein gene of isolate ck/CH/LHLJ/07VII, compared with those of Mass-type vaccine strains (table 6), indicating that it is unlikely that re-isolation of the vaccine strain was used in the flock immunization.

\section{Virulence Study: Recently Isolated IBVs Were}

Nephropathogenic in China

Clinical signs were observed 3-15 days after challenge in chicks from groups 1-4. The chicks were listless and huddled together, and showed ruffled feathers and a dark, shrunken comb. Some of the chicks suffered from severe gasping, coughing, conjunctivitis, nasal and ocular discharge, depression and weakness, and were reluctant to move. Some of the chicks in each challenged group died
Table 4. Comparison of $\mathrm{S} 1$ gene nucleotide sequence similarities of the isolate $\mathrm{ck} / \mathrm{CH} / \mathrm{LSD} 07-4$ with those of tl/CHLDT3/03 and $\mathrm{CK} / \mathrm{CH} / \mathrm{LSD} / 05 \mathrm{I}$

\begin{tabular}{llll}
\hline \multirow{2}{*}{ Strains } & \multicolumn{3}{l}{ ck/CH/LSD/07-4 } \\
\cline { 2 - 4 } & 1 to 1,620 & 1 to 582 & 622 to 1,620 \\
\hline tl/CHLDT3/03 & 92.8 & 80.9 & 99.3 \\
CK/CH/LSD/05I & 92.1 & 100 & 87.3 \\
\hline
\end{tabular}

The first 1,620 nucleotides, starting at the AUG translation start codon, of the entire S1 protein genes were compared. The sequence of potential recombination junction site (from 583 to 621) was not included in the comparison.

during the experimental period (table 3). Gross lesions of dead chicks were mainly confined to the kidneys, and were not dependent on which tissue the viruses were isolated from. The kidney parenchyma of the dead birds was pale, swollen and mottled; tubules and urethras were distended with uric acid crystals. Meanwhile, hemorrhagic lesions of cecal tonsils were observed in almost all of the challenged SPF chickens in the groups. However, no obvious gross lesions were observed in proventriculi of challenged chickens with isolates either from the proventriculus or from other tissue samples. The clinical signs of the inoculated birds tended to disappear gradually after 20 days of inoculation. Chickens in the control group had not shown clinical signs and gross lesions at autopsy.

Some chickens in the 4 challenged groups showed seroconversion by ELISA 5 days after challenge. All of the surviving birds showed seroconversion between 10 and 20 days after challenge (the antibody was not detected after 20 days after challenge; table 3). No animal in the unvaccinated control group showed seroconversion by ELISA during the experimental period. 


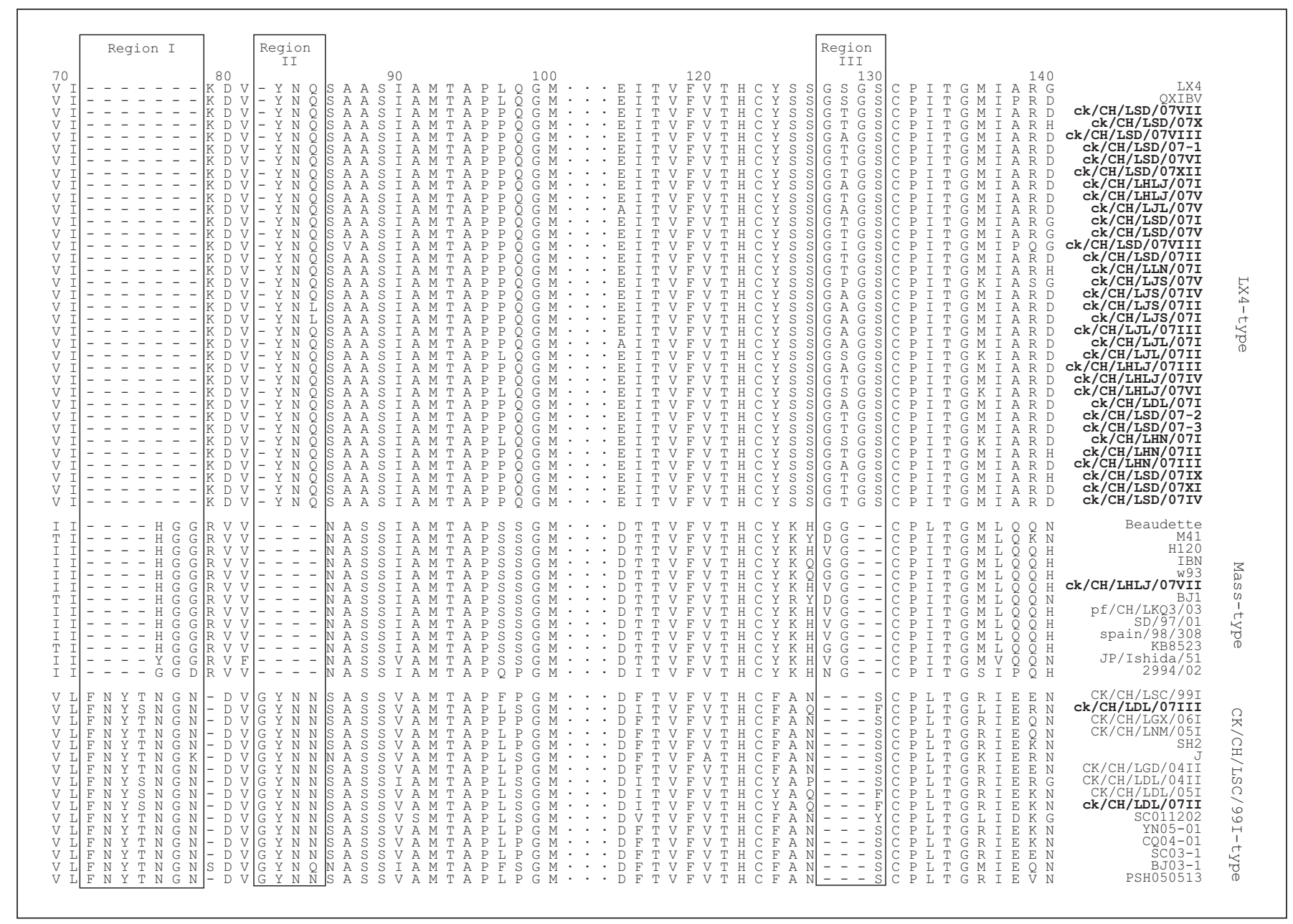

Fig. 3. Sequence alignment of $\mathrm{S} 1$ amino acid sequences from three different types of IBV. The nucleotide positions correspond to those in the sequence of the IBV Beaudette genome (GenBank accession number M95169). Those indicated are from positions 70 140; positions 101-115 are not indicated (represented by dots). The 3 unique deletion and insertion regions are boxed. The deleted nucleotides are represented as dashes. $\mathrm{K}=$ Lysine; $\mathrm{D}=$ aspartic acid; $\mathrm{V}=$ valine; $\mathrm{Y}$ = tyrosine; $\mathrm{N}$ = asparagine; $\mathrm{Q}=$ glutamine; $\mathrm{S}=$ serine; $\mathrm{A}=$ alanine $\mathrm{I}=$ isoleucine $\mathrm{M}=$ methionine; $\mathrm{T}$ = threonine; $\mathrm{P}=$ proline; $\mathrm{L}=$ leucine; $\mathrm{G}=$ glycine; $\mathrm{E}=$ glutamic acid; $\mathrm{F}=$ phenylalanine; $\mathrm{H}=$ histidine; $\mathrm{C}=$ cysteine $\mathrm{R}=$ arginine. Our IBV isolates are in bold type.

\section{Discussion}

IB has occurred frequently in recent years in China. It is one of the major poultry pathogens and causes heavy economic losses [20-27]. Meanwhile, different types of IBVs have co-circulated in chicken flocks in China [21, $23,24,26]$. These results suggest the need for dynamic and persistent surveillance of IBV in China. Liu et al. [36] showed that the A2-like virus, which is a 4/91-serotyperelated virus determined by neutralization test, was the predominant IBV type in chicken flocks. However, more detailed results from the present study, our previous reports $[15,23,26]$ and other published results in the GenBank database (Lu et al., unpubl. data; GenBank accession numbers: EU930416, EU930426-EU930437; $\mathrm{Wu}$ et al., unpubl. data; GenBank accession numbers: EU031525-EU031531) have shown that LX4-type IBVs are the major type of IBV that have been circulating in China in recent years. Furthermore, in China, as in Europe [3740], this type of IBV has increased in recent years. Both experimental infection and field results have shown that the available commercial vaccines provide little protec- 
Table 5. Comparison of S1 nucleotide and amino acid sequence similarities (\%) of the isolate ck/CH/LHLJ/07VII with those of reference Mass-type strains

\begin{tabular}{|c|c|c|c|c|c|c|c|c|c|c|c|c|c|}
\hline Strains & $\begin{array}{l}\mathrm{ck} / \mathrm{CH} / \\
\mathrm{LHLJ} / 07 \mathrm{VII}\end{array}$ & H120 & IBN & W93 & BJ1 & $\begin{array}{l}\mathrm{pf} / \mathrm{CH} / \\
\mathrm{LKQ} 3 / 03\end{array}$ & $\mathrm{SD} / 97 / 01$ & M41 & $\begin{array}{l}\text { Beau- } \\
\text { dette }\end{array}$ & $\begin{array}{l}\text { Spain/ } \\
98 / 308\end{array}$ & KB8523 & $\begin{array}{l}\text { JP/ } \\
\text { Ishida/51 }\end{array}$ & $2994 / 02$ \\
\hline ck/CH/LHLJ/07VII & & 98.7 & 98.2 & 98.2 & 95.0 & 98.8 & 99.0 & 95.6 & 95.6 & 98.7 & 98.0 & 96.3 & 90.6 \\
\hline $\mathrm{H} 120$ & 96.6 & & 99.2 & 99.2 & 96.0 & 99.5 & 99.3 & 96.6 & 96.3 & 100.0 & 99.0 & 97.3 & 91.3 \\
\hline IBN & 95.2 & 98.6 & & 100.0 & 95.6 & 99.0 & 98.8 & 96.3 & 96.1 & 99.2 & 98.8 & 96.8 & 91.0 \\
\hline W93 & 95.2 & 98.6 & 100.0 & & 95.6 & 99.0 & 98.8 & 96.3 & 96.1 & 99.2 & 98.8 & 96.8 & 91.0 \\
\hline BJ1 & 89.4 & 92.8 & 92.3 & 92.3 & & 95.8 & 95.6 & 99.3 & 96.0 & 96.0 & 95.8 & 96.3 & 91.3 \\
\hline $\mathrm{pf} / \mathrm{CH} / \mathrm{LKQ} 3 / 03$ & 96.6 & 99.0 & 97.6 & 97.6 & 91.8 & & 99.5 & 96.5 & 96.5 & 99.5 & 98.8 & 97.2 & 91.1 \\
\hline $\mathrm{SD} / 97 / 01$ & 97.1 & 98.6 & 97.1 & 97.1 & 91.3 & 98.6 & & 96.3 & 96.3 & 99.3 & 98.7 & 97.0 & 91.3 \\
\hline M41 & 90.3 & 93.7 & 93.2 & 93.2 & 99.0 & 92.8 & 92.3 & & 96.6 & 96.6 & 96.5 & 97.0 & 92.0 \\
\hline Beaudette & 91.8 & 94.2 & 93.7 & 93.7 & 91.3 & 94.2 & 93.7 & 92.3 & & 96.3 & 96.0 & 96.6 & 90.8 \\
\hline Spain/98/308 & 96.6 & 100.0 & 98.6 & 98.6 & 92.8 & 99.0 & 98.6 & 93.7 & 94.2 & & 99.0 & 97.3 & 91.3 \\
\hline KB8523 & 95.2 & 98.6 & 98.1 & 98.1 & 92.8 & 97.6 & 97.1 & 93.7 & 93.7 & 98.6 & & 96.6 & 90.8 \\
\hline JP/Ishida/51 & 91.3 & 94.7 & 93.2 & 93.2 & 92.3 & 93.7 & 93.2 & 93.2 & 92.8 & 94.7 & 93.2 & & 91.1 \\
\hline 2994/02 & 83.1 & 85.5 & 84.5 & 84.5 & 83.1 & 84.4 & 85.0 & 84.1 & 82.6 & 85.5 & 84.5 & 84.1 & \\
\hline
\end{tabular}

Nucleotide similarity is presented in the upper triangle of results, amino acid similarity in the lower one. The first 621 nucleotides starting at the AUG translation start codon of the S1 protein genes were compared because only 621 nucleotides were available for the JP/Ishida/51 strain. The reference strains were the same as in table 3.

Table 6. Pairwise comparison of nucleotides and amino acids in S1 gene of ck/CH/LHLJ/07VII with those of other Mass-type strains

\begin{tabular}{|c|c|c|c|c|c|c|c|c|c|c|c|c|c|c|c|c|c|c|c|c|c|c|}
\hline IBV strains & 19 & 35 & 41 & 64 & 117 & 117 & 118 & 147 & 147 & 151 & 159 & 182 & 226 & 232 & 237 & 247 & 249 & 252 & 253 & 261 & 337 & 529 \\
\hline CH/LHLJ/07VII & $\mathrm{V}$ & I & $\mathrm{D}$ & E & $\mathrm{H}$ & $\mathrm{H}$ & $\mathrm{V}$ & $\mathrm{V}$ & $\mathrm{V}$ & $\mathrm{N}$ & $\mathrm{H}$ & $\mathrm{Y}$ & I & $\mathrm{H}$ & $\mathrm{K}$ & $\mathrm{T}$ & $\mathrm{T}$ & $\mathrm{N}$ & $\mathrm{H}$ & $\mathrm{D}$ & $\mathrm{T}$ & 1 \\
\hline 120 (Vaccine) & A & $\mathrm{R}$ & $\mathrm{H}$ & G & $\mathrm{H}$ & $\mathrm{H}$ & V & $\mathrm{V}$ & $\mathrm{V}$ & $\mathrm{K}$ & Q & $\mathrm{D}$ & $\mathrm{R}$ & Q & $\mathrm{N}$ & $\mathrm{N}$ & $\mathrm{S}$ & $\mathrm{K}$ & Q & $\mathrm{N}$ & $\mathrm{N}$ & $\mathrm{T}$ \\
\hline $3 \mathrm{~N}$ (Vaccine) & A & $\mathrm{R}$ & $\mathrm{H}$ & G & Q & Q & G & S & $\mathrm{S}$ & $\mathrm{K}$ & Q & $\mathrm{D}$ & $\mathrm{R}$ & Q & $\mathrm{N}$ & $\mathrm{N}$ & $\mathrm{S}$ & $\mathrm{K}$ & Q & $\mathrm{N}$ & $\mathbf{N}$ & $\mathrm{T}$ \\
\hline 193 (Vaccine) & A & $\mathrm{R}$ & $\mathrm{H}$ & G & Q & Q & G & $\mathrm{S}$ & S & $\mathrm{K}$ & Q & $\mathrm{D}$ & $\mathrm{R}$ & Q & $\mathrm{N}$ & $\mathrm{N}$ & S & $\mathrm{K}$ & Q & $\mathrm{N}$ & N & $\mathrm{T}$ \\
\hline 1 (China & A & $\mathrm{R}$ & $\mathrm{H}$ & G & $\mathrm{Y}$ & $\mathrm{Y}$ & $\mathrm{D}$ & $\mathrm{V}$ & V & $\mathrm{K}$ & Q & $\mathrm{D}$ & $\mathrm{R}$ & Q & $\mathrm{N}$ & $\mathrm{N}$ & $S$ & $\mathrm{~K}$ & Q & $\mathrm{N}$ & NA & NA \\
\hline 03 (China & $\mathrm{V}$ & $\mathrm{R}$ & $\mathrm{H}$ & G & $\mathrm{H}$ & $\mathrm{H}$ & V & $\mathrm{V}$ & V & $\mathrm{K}$ & Q & $\mathrm{D}$ & $\mathrm{K}$ & Q & $\mathrm{N}$ & $\mathrm{N}$ & $\mathrm{S}$ & $\mathrm{K}$ & Q & $\mathrm{N}$ & $\mathrm{N}$ & 1 \\
\hline $\mathrm{SD} / 9$ & $\mathrm{~V}$ & $\mathrm{R}$ & $\mathrm{H}$ & $\mathrm{E}$ & $\mathrm{H}$ & $\mathrm{H}$ & V & $\mathrm{V}$ & V & $\mathrm{K}$ & Q & $\mathrm{D}$ & $\mathrm{K}$ & Q & $\mathrm{N}$ & $\mathrm{N}$ & $\mathrm{S}$ & $\mathrm{K}$ & Q & $\mathrm{N}$ & t & $\mathrm{T}$ \\
\hline & A & $\mathrm{R}$ & $\mathrm{H}$ & G & $\mathrm{Y}$ & $\mathrm{Y}$ & $\mathrm{D}$ & $\mathrm{V}$ & V & $\mathrm{K}$ & Q & D & $\mathrm{K}$ & Q & $\mathrm{N}$ & $\mathrm{N}$ & $\mathrm{S}$ & $\mathrm{K}$ & Q & $\mathrm{N}$ & $\mathrm{N}$ & $\mathrm{T}$ \\
\hline Beau & $\mathrm{V}$ & $\mathrm{R}$ & $\mathrm{H}$ & G & $\mathrm{H}$ & $\mathrm{H}$ & G & $\mathrm{V}$ & V & $\mathrm{K}$ & Q & $\mathrm{D}$ & $\mathrm{R}$ & Q & $\mathrm{N}$ & $\mathrm{N}$ & $S_{2}$ & $\mathrm{~K}$ & Q & $\mathrm{N}$ & $\mathrm{N}$ & $\mathrm{T}$ \\
\hline t) & A & $\mathrm{R}$ & $\mathrm{H}$ & G & $\mathrm{H}$ & $\mathrm{H}$ & V & $\mathrm{V}$ & V & $\mathrm{K}$ & Q & $\mathrm{D}$ & $\mathrm{R}$ & $Q$ & $\mathrm{~N}$ & $\mathrm{~N}$ & 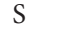 & $\mathrm{K}$ & Q & $\mathrm{N}$ & $\mathrm{N}$ & $\mathrm{T}$ \\
\hline & A & $\mathrm{R}$ & $\mathrm{H}$ & G & $\mathrm{H}$ & $\mathrm{H}$ & G & $\mathrm{V}$ & V & $\mathrm{K}$ & Q & $\mathrm{D}$ & $\mathrm{R}$ & Q & $\mathrm{N}$ & $\mathrm{N}$ & & $\mathrm{K}$ & Q & $\mathrm{N}$ & $\mathrm{N}$ & $\mathrm{T}$ \\
\hline JP/ & A & $\mathrm{R}$ & $\mathrm{H}$ & G & $\mathrm{H}$ & $\mathrm{H}$ & $\mathrm{V}$ & $\mathrm{V}$ & $\mathrm{V}$ & $\mathrm{K}$ & Q & D & $\mathrm{R}$ & Q & $\mathrm{N}$ & $\mathrm{N}$ & & $\mathrm{K}$ & $\mathrm{Q}$ & $\mathrm{N}$ & NA & NA \\
\hline 2994/02 (Taiwan) & A & $\mathrm{R}$ & $\mathrm{H}$ & E & $\mathrm{H}$ & $\mathrm{H}$ & $\mathrm{N}$ & $\mathrm{V}$ & V & $\mathrm{K}$ & Q & $\mathrm{D}$ & $\mathrm{R}$ & Q & $\mathrm{N}$ & $\mathrm{N}$ & $S$ & $\mathrm{~K}$ & Q & $\mathrm{N}$ & $\mathrm{N}$ & $\mathrm{T}$ \\
\hline
\end{tabular}

We compared the nucleotides and deduced amino acids in the $\mathrm{S} 1$ gene of isolate ck/CH/LHLJ/07VII from the AUG translation start codon to the cleavage recognition sites. Of the 25 mutations occurring in the gene, three $(645,846$ and 939$)$ were synonymous and did not result in amino acid substitutions compared with those of the other reference strains.

$\mathrm{V}=$ Valine; $\mathrm{A}=$ alanine; $\mathrm{I}=$ isoleucine; $\mathrm{R}=\operatorname{arginine} ; \mathrm{D}=$ aspartic acid; $\mathrm{H}=$ histidine; $\mathrm{E}=$ glutamic acid $\mathrm{G}=$ glycine; $\mathrm{Q}=$ glutamine; $\mathrm{Y}=$ tyrosine; $\mathrm{N}$ = asparagine; $\mathrm{S}=$ serine; $\mathrm{K}=$ lysine; $\mathrm{T}=$ threonine; $\mathrm{NA}=$ not available.

tion against the LX4-type IBV [30], which suggests a need to develop vaccines from LX-type local strains.

Extremely large (+) RNA virus genomes, such as those of coronaviruses, are thought to mutate at a high frequency as a consequence of the high error rates of the RNA polymerases. They are predicted to accumulate several base substitutions per round of replication. As for IBV, evolution and mutation rates in the face of vaccination are determined to be 2.5 and $1.5 \%$ per year, respectively; however, in the absence of vaccines, IBV lineages appear 
to evolve at a much slower rate (0.3\%) [14]. Though extensive IB vaccination was conducted in China, high sequence similarities (more than $95.1 \%$ nucleotide similarity) were shared between the newly isolated LX4-type IBVs in this study and the previously published LX4 and QXIBV strains isolated 10 years ago [23]. This may be due to the poor protection supplied by the vaccines.

The evolution of IBVs appears to be influenced by many factors, such as the use of multiple strains for vaccination, population density and host immune status [41]. In addition, transcription of IBV RNA genomes has a high error rate $[42,43]$. Taken together, these factors have resulted in genetic diversity among the IBV genome generated by point mutations, insertions and deletions introduced into the viral genome. In the present study, variations resulting from point mutations were noted throughout the S1 gene, both within the same type and between different types when the sequences were aligned. However, when the S1 sequences were compared between different types, 3 unique insertions and deletions were found. The unique insertions and deletions in the S1 protein shared by the same type of viruses may reflect the fact that these viruses may have a common ancestor in the course of evolution, and that these unique regions can be used as markers in virus detection, identification and even typing.

Another important mechanism for IBV genetic evolution is the high frequency of homologous RNA recombination. This process is believed to be mediated by a 'copychoice' mechanism [44]. Recombination of IBV genomes has been observed during growth in experimental infected animals and in embryonated eggs $[45,46]$. There is also evidence for recombination in IBV in the field [4751]. In most cases, evidence of the recombinant event in IBV in field conditions and the potential recombination breakpoint were predicted using bioinformatic methods, such as phylogenetic analysis, to compare the sequences between different genomic regions [47-51]. In this study, $\mathrm{ck} / \mathrm{CH} / \mathrm{LSD} / 07-4$ has the CK/CH/LSD/05I-like sequence in the first third of the $\mathrm{S} 1$ gene and the $\mathrm{tl} / \mathrm{CH} / \mathrm{LDT} 3 / 03$ like sequence in the latter two thirds of the gene, showing that isolate ck/CH/LSD/07-4 might come from the direct recombination between $\mathrm{tl} / \mathrm{CH} / \mathrm{LDT} 3 / 03$-like and $\mathrm{CK} /$ $\mathrm{CH} / \mathrm{LSD} / 05 \mathrm{I}-$ like viruses. The $\mathrm{tl} / \mathrm{CH} / \mathrm{LDT} 3 / 03$ was isolated in 2003 from a teal in Guangdong province, China [26] and CK/CH/LSD/05I was isolated in 2005 in Shandong province, China [27]. The isolation of $\mathrm{ck} / \mathrm{CH} /$ LSD/07-4 and the recombination occurred in the course of its evolution suggested that $\mathrm{tl} / \mathrm{CH} / \mathrm{LDT} 3 / 03$-like virus could replicate and circulate in domestic fowl (chickens) in natural conditions, further confirming our previous hypothesis that this virus might be spread to the teal from nearby chickens [26].

As in many other parts of the world, Mass-type vaccines are the primary, officially authorized vaccines in China. Despite the use of these IBV vaccines, it is common to find IB problems in vaccinated chickens, just as was found in this study. We isolated a Mass-type IBV isolate in an H120-vaccinated layer hen; however, genetic analysis revealed that it is unlikely to be a re-isolation of the vaccine strain used in the immunization. Many reports have shown that differences in only a few amino acids within the S1 protein can result in a different serotype $[11,52]$. Escape mutants of Mass 41 possessed a single amino acid substitution at position 63 (equivalent to our position 64), and this provides evidence of a neutralization epitope being located within the HVR1 of the S1 glycoprotein [53]. In this study, we found an amino acid substitution $\mathrm{E}$ at the position $64 \mathrm{of} \mathrm{ck} / \mathrm{CH} / \mathrm{LHLJ} / 07 \mathrm{VII}$ instead of G in the Mass-type vaccines, such as H120, IBN and W93 (table 2). However, we could not conclude that the existence of ck/CH/LHLJ/07VII in the H120-vaccinated chicken resulted from poor protection by $\mathrm{H} 120$ due to the genetic diversity and unsuitable vaccination program or immunosuppression. Further, no other factor that results in immune failure could be excluded.

It was reported that, although IBV strains of different pathogenicities were cocirculating in chicken flocks in China [27], nephropathogenicity was the predominant type of pathogenicity [20-26]. Parallel to those reports, our results in this study showed that all 4 selected IBV isolates were nephropathogenic, no matter what tissues they were isolated from. Like the previously isolated LX4type IBVs [23], the isolate $\mathrm{ck} / \mathrm{CH} / \mathrm{LDL} / 07 \mathrm{I}$, which was isolated in the kidney of a diseased chicken, had comparable virulence to SPF chickens and also primarily caused nephrosis by experimental infection. In the mid-1990s, several study groups in China reported a type of IBV that had high affinity to the proventriculus of chicken and implicated a 'novel' pathogenicity of IBV associated with transmissible proventriculitis [54]. However, few of the experimental reproductions of proventriculitis have succeeded using those isolated IBVs. In this study, we used 2 LX4-type IBVs isolated from proventriculi of chickens with severe proventriculitis to attempt to experimentally produce proventriculitis. Interestingly, chickens infected with both of the isolates showed obvious nephritis, and no proventriculitis was observed. This result was similar to those from other countries. LX4-type IBVs are one of the main types of IBV in European countries; however, 
no reports of proventriculitis have been associated with this type of IBV, but it has caused nephritis and false layers in mature hens [38]. Another genotype of IBV which is associated with proventriculitis in China has also been isolated in Taiwan provinces and was found to cause nephritis, but not proventriculitis [34]. In fact, we found that all 6 IBV-positive samples with proventriculitis were co-infected with reticuloendothelial virus and avian leukosis virus subgroup J, although other potential causative agents were not detected in this study (not shown). These findings raise the possibility that IBV may be only a by- stander virus present in chickens with proventriculitis disease due to other causative agents, rather than being directly involved in the disease etiology. The pathogenicity of IBV in China in recent years was nephropathogenic.

\section{Acknowledgment}

This work was funded by a grant from the National Key Technology R\&D Program of the Ministry of Science and Technology of PR China (No. 2006BAD06A03).

\section{References}

-1 Vijaykrishna D, Smith GJ, Zhang JX, Peiris JS, Chen H, Guan Y: Evolutionary insights into the ecology of coronaviruses. J Virol 2007;81:4012-4020.

2 Lai MMC, Cavanagh D: The molecular biology of coronaviruses. Adv Virus Res 1997;48: $1-100$.

3 Cavanagh D: Coronavirus avian infectious bronchitis virus. Vet Res 2007;38:281-297.

-4 Cavanagh D, Davis PJ, Darbyshire JH, Peters RW: Coronavirus IBV: virus retaining spike glycopolypeptide S2 but not S1 is unable to induce virus-neutralizing or haemagglutination-inhibiting antibody, or induce chicken tracheal protection. J Gen Virol 1986;67: 1435-1442.

5 Koch G, Hartog L, Kant A, van Roozelaar DJ: Antigenic domains on the peplomer protein of avian infectious bronchitis virus: correlation with biological functions. J Gen Virol 1990;71:1929-1935.

-6 Niesters HG, Bleumink-Pluym NM, Osterhaus AD, Horzinek MC, van der Zeijst BA: Epitopes on the peplomer protein of infectious bronchitis virus strain M41 as defined by monoclonal antibodies. Virology 1987; 161:511-519.

7 Masters PS: The molecular biology of coronaviruses. Adv Virus Res 2006;66:193-292.

$\checkmark 8$ Adzhar A, Gough RE, Haydon D, Shaw K, Britton P, Cavanagh D: Molecular analysis of the 793/B serotype of infectious bronchitis virus in Great Britain. Avian Pathol 1997;26: 625-640.

$\checkmark 9$ Cavanagh D, Davis PJ: Coronavirus IBV: removal of spike glycopolypeptide S1 by urea abolishes infectivity and haemagglutination but not attachment to cells. J Gen Virol 1986; 67:1443-1448.

10 Cavanagh D, Davis PJ, Darbyshire JH, Peters RW: Coronavirus IBV: virus retaining spike glycopolypeptide S2 but not S1 is unable to induce virus-neutralizing or haemagglutination-inhibiting antibody, or induce chicken tracheal protection. J Gen Virol 1986;67: 1435-1442.
11 Cavanagh D, Davis PJ, Cook JKA, Li D, Kant A, Koch G: Location of the amino acid differences in the S1 spike glycoprotein subunit of closely related serotypes of infectious bronchitis virus. Avian Pathol 1992;21:3343.

12 Kant A, Koch G, van Roozelaar DJ, Kusters JG, Poelwijk FA, van der Zeijst BA: Location of antigenic sites defined by neutralizing monoclonal antibodies on the S1 avian infectious bronchitis virus glycopolypeptide. J Gen Virol 1992;73:591-596.

13 Koch G, Hartog L, Kant A, van Roozelaar DJ: Antigenic domains on the peplomer protein of avian infectious bronchitis virus: correlation with biological functions. J Gen Virol 1990;71:1929-1935.

14 Lee CW, Jackwood MW: Origin and evolution of Georgia 98 (GA98), a new serotype of avian infectious bronchitis virus. Virus Res 2001;80:33-39.

15 Liu S, Zhang Q, Chen J, Han Z, Liu X, Feng L, Shao Y, Rong J, Kong X, Tong G: Genetic diversity of avian infectious bronchitis coronavirus strains isolated in China between 1995 and 2004. Arch Virol 2006;151:11331148.

16 Mase M, Tsukamoto K, Imai K, Yamaguchi S: Phylogenetic analysis of avian infectious bronchitis virus strains isolated in Japan. Arch Virol 2004;149:2069-2078.

17 Moore KM, Bennett JD, Seal BS, Jackwood MW: Sequence comparison of avian infectious bronchitis virus S1 glycoproteins of the Florida serotype and five variant isolates from Georgia and California. Virus Genes 1998; 17:63-83.

18 Wang CH, Huang YC: Relationship between serotypes and genotypes based on the hypervariable region of the S1 gene of infectious bronchitis virus. Arch Virol 2000;145:291300 .
19 Dolz R, Pujols J, Ordóñez G, Porta R, Majó $\mathrm{N}$ : Molecular epidemiology and evolution of avian infectious bronchitis virus in Spain over a fourteen-year period. Virology 2008; 374:50-59.

-20 Wang HN, Wu QZ, Huang Y, Liu P: Isolation and identification of infectious bronchitis virus from chickens in Sichuan, China. Avian Dis 1997;41:279-282.

21 Li H, Yang HC: Sequence analysis of nephropathogenic infectious bronchitis virus strains of the Massachusetts genotype in Beijing. Avian Pathol 2001;30:535-541.

22 Yu L, Wang Z, Jiang Y, Low S, Kwang J: Molecular epidemiology of infectious bronchitis virus isolates from China and Southeast Asia. Avian Dis 2001;45:201-209.

23 Liu S, Kong X: A new genotype of nephropathogenic infectious bronchitis virus circulating in vaccinated and nonvaccinated flocks in China. Avian Pathol 2004;33:321327.

24 Bing GX, Liu X, Pu J, Liu QF, Wu QM, Liu JH: Different genotypes of nephropathogenic infectious bronchitis viruses co-circulating in chicken population in China. Virus Genes 2007;35:333-337.

25 Xu C, Zhao J, Hu X, Zhang G: Isolation and identification of four infectious bronchitis virus strains in China and analyses of their S1 glycoprotein gene. Vet Microbiol 2007; 122:61-71.

26 Liu S, Chen J, Chen J, Kong X, Shao Y, Han Z, Feng L, Cai X, Gu S, Liu M: Isolation of avian infectious bronchitis coronavirus from domestic peafowl (Pavo cristatus) and teal (Anas). J Gen Virol 2005;86:719-725.

27 Liu S, Wang Y, Ma Y, Han Z, Zhang Q, Shao Y, Chen J, Kong X: Identification of a newly isolated avian infectious bronchitis coronavirus variant in china exhibiting affinity for the respiratory tract. Avian Dis 2008;52: 306-314. 
-28 Qian DH, Zhu GJ, Wu LZ, Hua GX: Isolation and characterization of a coronavirus from pigeons with pancreatitis. Am J Vet Res 2006;67:1575-1579.

-29 Bijlenga G, Cook JKA, Gelb J Jr, de Wit JJ: Development and use of the $\mathrm{H}$ strain of avian infectious bronchitis virus from the Netherlands as a vaccine: a review. Avian Pathol 2004;33:550-557.

-30 Liu S, Chen J, Han Z, Zhang Q, Shao Y, Kong $\mathrm{X}$, Tong G: Infectious bronchitis virus: S1 gene characteristics of vaccines used in China and efficacy of vaccination against heterologous strains from China. Avian Pathol 2006;35:394-399.

-31 Boursnell MEG, Brown TDK, Foulds IJ, Green PF, Tomlet FM, Binns MM: Completion of the sequence of the genome of the coronavirus avian infectious bronchitis virus. J Gen Virol 1987;68:57-77.

\32 CallisonSA, Hilt DA, Boynton TO, Sample BF, Robison R, Swayne DE, Jackwood MW: Development and evaluation of a real-time Taqman RT-PCR assay for the detection of infectious bronchitis virus from infected chickens. J Virol Methods 2006;138:60-65.

-33 Sutou S, Sato S, Okabe T, Nakai M, Sasaki N: Cloning and sequencing of genes encoding structural proteins of avian infectious bronchitis virus. Virology 1988;165:589-595.

$\checkmark 34$ Huang YP, Lee HC, Cheng MC, Wang CH: $\mathrm{S} 1$ and $\mathrm{N}$ gene analysis of avian infectious bronchitis viruses in Taiwan. Avian Dis 2004;48:581-589.

35 de Wit JJ, de Jong MCM, Pijpers A, Verheijden JHM: Transmission of infectious bronchitis virus within vaccinated and unvaccinated groups of chickens. Avian Pathol 1998; 27:464-471.
36 Liu XL, Su JL, Zhao JX, Zhang GZ: Complete genome sequence analysis of a predominant infectious bronchitis virus (IBV) strain in China. Virus Genes 2009;38:56-65.

37 Bochkov YA, Batchenko GV, Shcherbakova LO, Borisov AVL, Drygin VV: Molecular epizootiology of avian infectious bronchitis in Russia. Avian Pathol 2006;35:379-393.

38 Domanska-Blicharz K, Minta Z, Smietanka K, Porwan T: New variant of IBV in Poland. Vet Rec 2006;158:808.

39 Worthington KJ, Jones RC: New genotype of infectious bronchitis virus in chickens in Scotland. Vet Rec 2006;159:291-292.

$\checkmark 40$ Gough RE, Cox WJ, de B Welchman D, Worthington KJ, Jones RC: Chinese QX strain of infectious bronchitis virus isolated in the UK. Vet Rec 2008;162:99-100.

41 Domingo E, Martínez-Salas E, Sobrino F, de la Torre JC, Portela A, Ortín J, López-Galindez C, Pérez-Breña P, Villanueva N, Njera R The quasispecies (extremely heterogeneous) nature of viral RNA genome population: biological relevance: a review. Gene 1985;40: $1-8$.

42 Lee CW, Hilt DA, Jackwood MW: Redesign of primer and application of the reverse transcriptase-polymerase chain reaction and restriction fragment length polymorphism test to the DE072 strain of infectious bronchitis virus. Avian Dis 2000;44:650-654.

43 Lee SK, Sung HW, Kwon HM: S1 glycoprotein gene analysis of infectious bronchitis viruses isolated in Korea. Arch Virol 2004;149: 481-494.

44 Masters PS: The molecular biology of coronaviruses. Adv Virus Res 2006;66:193-292.

45 Kottier SA, Cavanagh D, Britton P: Experimental evidence of recombination in coronavirus infectious bronchitis virus. Virology 1995;213:569-580.

-46 Wang L, Xu Y, Collisson EW: Experimental confirmation of recombination upstream of the S1 hypervariable region of infectious bronchitis virus. Virus Res 1997;49:139145.
-47 Kusters JG, Jager EJ, Niesters HG, van der Zeijst BA: Sequence evidence for RNA recombination in field isolates of avian coronavirus infectious bronchitis virus. Vaccine 1990;8:605-608.

48 Cavanagh D, Davis PJ, Cook JK: Infectious bronchitis virus: evidence for recombination within the Massachusetts serotype. Avian Pathol 1992;21:401-408.

49 Wang L, Junker D, Collisson EW: Evidence of natural recombination within the S1 gene of infectious bronchitis virus. Virology 1993; 192:710-716.

50 Jia W, Karaca K, Parrish CR, Naqi SA: A novel variant of avian infectious bronchitis virus resulting from recombination among three different strains. Arch Virol 1995;140:259271.

51 Lee CW, Jackwood MW: Evidence of genetic diversity generated by recombination among avian coronavirus IBV. Arch Virol 2000; 145: 2135-2148.

52 Wang L, Junker D, Hock L, Ebiary E, Collisson EW: Evolutionary implications of genetic variations in the $\mathrm{S} 1$ gene of infectious bronchitis virus. Virus Res 1994;34:327338.

53 Cavanagh D, Davis PJ, Mockett APA: Amino acids within hypervariable region 1 of avian coronavirus IBV (Massachusetts serotype) spike glycoprotein are associated with neutralization epitopes. Virus Res 1988;11:141150.

54 Yu L, Jiang Y, Low S, Wang Z, Nam SJ, Liu W, Kwang J: Characterization of three infectious bronchitis virus isolates from China associated with proventriculus in vaccinated chickens. Avian Dis 2001;45:416-424. 